\title{
Evaluation of chemokines and receptors in gnotobiotic root canal infection by F. nucleatum and $E$. faecalis
}

\section{Caroline Christine SANTA-ROSA ${ }^{(a)}$ Marcela Marçal THEBIT(a) Kamilla Faria MACIEL ${ }^{(a)}$ Luciana Carla Neves de BRITO(b) Leda Quercia VIEIRA (c) Antônio Paulino RIBEIRO-SOBRINHO(a)}

(a) Universidade Federal de Minas Gerais UFMG, Faculty of Dentistry, Department of Restorative Dentistry, Belo Horizonte, MG, Brazil.

(b)Fundação Universidade de Itaúna - FUI, Faculty of Dentistry, Itaúna, MG, Brazil.

(c) Universidade Federal de Minas Gerais UFMG, Institute of Biological Sciences, Department of Biochemistry and Immunology, Belo Horizonte, MG, Brazil.

Declaration of Interest: The authors certify that they have no commercial or associative interest that represents a conflict of interest in connection with the manuscript.

\section{Corresponding Author:}

Antônio Paulino Ribeiro Sobrinho

E-mail: sobrinho.bhz@gmail.com

hitps://doi.org/10.1590/1807-3107bor-2018.vol32.0120

Submitted: April 17, 2018

Accepted for publication: September 24, 2018

Last revision: October 10, 2018
Abstract: The present study aims to evaluate the longitudinal effects of induced experimental infections in gnotoxenic animals on the expression of inflammatory chemokines and their receptors in periradicular tissues. The null hypothesis tested was that Enterococcus faecalis and Fusobacterium nucleatum had no effect on CCR5, CCL5, CXCL10, CCL2/MCP-1, CXCR2 and CCR1 expression. Two groups of five animals $(n=5)$ aged between 8 and 12 weeks were used in this study. The animals were anaesthetized, and coronary access was performed in the first molar on the right and left sides. Microorganisms were inoculated into the left molar, and the right molar was sealed without contamination to function as a control. Animals were sacrificed 7 and 14 days after infection, and periapical tissues were collected. The cytokine mRNA expression levels were assessed using realtime PCR. The chemokine mRNA expression levels demonstrated that the experimental infection was capable of inducing increased chemokine expression on day 7 compared to that on day 14, except for CCR5 and CCL5, which showed no changes. The gnotoxenic animal model proved to be effective and allowed evaluation of the immune response against a known infection. Additionally, this study demonstrates that gene expression of chemokines and their receptors against the experimental infection preferentially prevailed during the initial phase of induction of the periradicular alteration (i.e., on day 7 post-infection).

Keywords: Germ-free Life; Chemonikes; Periapical Diseases; Microbiology.

\section{Introduction}

Disruption of the integrity of mineralized tissues, enamel, and dentin promotes the entry of harmful elements to the pulp, which can lead to its inflammation and consequent tissue destruction ${ }^{1}$. The interaction between bacterial irritants and the host defence response results in the release of innumerable mediators that are capable of stimulating immune responses in

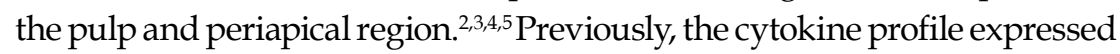
in the periapical tissues of gnotoxenic animals in response to root canal infections was demonstrated to depend on the bacterial challenge, because each species induced specific host immune responses. ${ }^{6,7,8,9}$

Among the mediators involved in pulpal and periradicular disorders, the number of chemokines is outstanding. Chemokines are members 
of the family of cytokine regulatory proteins that have low molecular weights and stimulate leukocyte recruitment. ${ }^{10,11,12}$ Moreover, chemokines and their receptors, such as CCL2/MCP-1, CCR/5, CXCL10, CCL5, CXCR2, and many others, are involved in many biological processes, including homeostasis and immune activation and regulation. ${ }^{910,12}$ Chemokines act by binding to membrane receptors, which can bind to more than one chemokine. ${ }^{13}$

Many studies have been performed to elucidate the dynamics of the immune mechanisms that occur at the root apex of infection-bearing teeth by exposing the pulp to the oral microbiota. ${ }^{4,5,9,14,15,16,17,18,19}$ To improve this model, researchers have induced experimental infections with a known microbiota in germ-free (GF) animals. 2,6,7,7,20

The present study aims to evaluate the longitudinal effects of induced experimental infections in GF animals on the expression of chemokines and their receptors in the periradicular tissues of these animals. The null hypothesis tested was that Enterococcus faecalis and Fusobacterium nucleatum had no effect on CCR5, CCL5, CXCL10, CCL2/MCP-1, CXCR2 and CCR1 expression.

\section{Methodology}

\section{Mice}

Germ-free mice aged 4-8 weeks (Swiss/NIH, ICB, Universidade Federal de Minas Gerais, Belo Horizonte, Brazil) were maintained in Trexler-type isolators (Class Biologically Clean, Madison, WI, USA). For the experimental procedures, the animals were transferred into microisolators (UNO Roestvastaal BV, Zevenaar, the Netherlands). All manipulations were performed under sterile conditions in a laminar flow hood (Veco, Campinas, Brazil). The animals were fed ad libitum. The animal ethics committee approved the experimental protocol (254/2013, CETEA/UFMG).

\section{Microorganisms}

The microorganisms inoculated in the root canal system (RCS) of the GF mice were the reference strains F. nucleatum (ATCC 10953) and E. faecalis (ATCC19433). The bacteria were maintained at $-86^{\circ} \mathrm{C}$ and recovered in broth-heart infusion medium (BHI) supplemented with yeast extract, hemin and menadione (BHI-SPRAS) (Difco, Detroit, USA). The microbial suspension with both strains was adjusted to approximately $10^{7} \mathrm{CFU}$ in $25 \mu \mathrm{L}$ of the same medium (BHI-SPRAS, Difco) in which the species were grown. Incubations were performed at $37^{\circ} \mathrm{C}$ in an anaerobic chamber containing $85 \% \mathrm{~N}_{2}, 10 \% \mathrm{H}_{2}$ and $5 \% \mathrm{CO}_{2}$ (Forma Scientific Company, Marietta, USA).

\section{Experimental root canal infection}

The experimental procedures were performed with the animals under general anaesthesia; the animals were anaesthetized using $100 \mathrm{mg} \mathrm{kg}^{-1}$ of ketamine hydrochloride (Dopalen, Division Vetbrands Animal Health, Jacareí, Brazil) and $10 \mathrm{mg} \mathrm{kg}^{-1}$ of xylazine (Anasedan, Agribrands do Brasil Ltda, Paulínia, Brazil). The pulpal chamber of the maxillary right first molar was accessed under an endodontic operative microscope (Alliance, São Paulo, SP, Brazil) with a one-fourth carbide bur (KG Sorensen, Barueri, Brazil) coupled to a controlled rotation handpiece (Driller, São Paulo, Brazil). The pulp chambers were opened until the orifices of the canals could be visualized and probed with a size 8 and $10 \mathrm{~K}$-file (Dentsply, Maillefer, Ballaigues, Switzerland). The right molar was not inoculated and was used as a control. The left molar received inoculation of the microbial suspension, which was adjusted to approximately $10^{7} \mathrm{CFU}$ in $25 \mu \mathrm{L}$ of the same medium (BHI-SPRAS, Difco) in which the species were grown. The bacterial suspensions were inoculated into the RCS using tuberculin syringes and needles. After inoculation, the teeth were sealed with Coltosol ${ }^{21}{ }^{21}$

\section{Sample preparation}

The mice were sacrificed at 7 and 14 days after root canal inoculation. The periapical tissues surrounding the root apices and the bone subjected to surgery were aseptically removed, rinsed in phosphate-buffered saline, flash-frozen in a mixture of dry ice and ethanol and stored at $-70^{\circ} \mathrm{C}$. Total periapical tissues and bone RNA were isolated using the TRIzol reagent (Gibco/BRL Laboratories, Grand Island, USA). After the addition of TRIzol, chloroform was added, and the mixture was centrifuged at $12,000 \times \mathrm{g}$ at $4^{\circ} \mathrm{C}$ for $15 \mathrm{~min}$. The aqueous phase was collected, and the 
RNA was precipitated by the addition of isopropanol followed by centrifugation at $12000 \times \mathrm{g}$ at $4^{\circ} \mathrm{C}$ for 10 $\mathrm{min}$. The precipitated RNA was washed once with cold $75 \%$ ethanol, dried, dissolved in RNase-free water, incubated at $55^{\circ} \mathrm{C}$ for $10 \mathrm{~min}$ and then stored at $-70^{\circ} \mathrm{C}$.

\section{Real-time PCR}

Complementary DNA was synthesized using 2 mg of RNA by reverse transcription as previously described..$^{22}$ The standard PCR conditions were as follows: a holding stage of $95^{\circ} \mathrm{C}$ for $10 \mathrm{~min}$; a cycling stage with 40 cycles of $95^{\circ} \mathrm{C}$ for $15 \mathrm{~s}$ and $60^{\circ} \mathrm{C}$ for $1 \mathrm{~min}$; and a melting curve stage of 95 ${ }^{\circ} \mathrm{C}$ for $15 \mathrm{~s}, 60^{\circ} \mathrm{C}$ for $1 \mathrm{~min}$, and $95^{\circ} \mathrm{C}$ for $15 \mathrm{~s}$. The primer sequences used for analysis of CCR5, CCL5, CXCL10, CCL2/MCP-1, CXCR2 and CCR1 mRNA expression by quantitative real-time PCR are shown in Table. The real-time PCR was performed using the Step One Real-time PCR System (Applied Biosystems, Foster City, USA). The SYBR Green detection system (Applied Biosystems) was used to assay primer amplification. The housekeeping gene hypoxanthine phosphoribosyltransferase (HPRT) was also amplified and used to normalize the mRNA expression levels. All samples were run in duplicate in a $20-\mathrm{mL}$ reaction volume with $1 \mathrm{mg}$ of cDNA. The Sequence Detection Software, version v 2.0 (Applied Biosystems) was used to analyse the data after amplification. The results were obtained as threshold cycle $\left(C_{t}\right)$ values, which represented the cycle number at which the fluorescence levels passed a fixed threshold. The expression levels were calculated using the ${ }^{\mathrm{DD}} \mathrm{C}_{\mathrm{t}}$ method. The $\mathrm{C}_{\mathrm{t}}$ values are expressed as the mean of two independent measurements, and the mRNA expression levels for all samples are expressed as the ratio between the expression of the gene of interest and HPRT expression. All data were analysed using the SPSS 22 statistical program (SPSS Inc., Chicago, USA). Levene's test was used to assess the equality of variance of the data, whereas a t-test for independent samples was used to evaluate the significance of the differences observed between groups. Differences in mRNA expression levels were considered to be statistically significant when the $\mathrm{p}$-value was $<0.05$.
Table. Primer sequences.

\begin{tabular}{|c|c|c|}
\hline Gene & Sense and antisense & $\begin{array}{l}\text { Length } \\
\text { (bp) }\end{array}$ \\
\hline \multirow{2}{*}{ HPRT } & 5'-GTT GGA TAC AGG CCA GAC TाT GTT G-3' & \multirow{2}{*}{162} \\
\hline & 5'-GAT TCA ACT TGC CGT CAT CTT AGG C-3' & \\
\hline \multirow{2}{*}{ CXCL10 } & 5'-CTC GCA AGG ACG GTC CGC TG-3' & \multirow{2}{*}{193} \\
\hline & 5'-CTC GCA AGG ACG GTC CGC TG-3' & \\
\hline \multirow{2}{*}{ CCL2 } & 5'-AGG AAG ATC TCA GTG CAG AG-3' & \multirow{2}{*}{92} \\
\hline & 5'-AGT CTT CGG AGT TTG CCT TTG-3' & \\
\hline \multirow{2}{*}{ CCL5 } & 5'-CGT GCC CAC ATC AAG GAG TA-3' & \multirow{2}{*}{91} \\
\hline & 5'-CAC ACA CTT GGC GGT TCT TTC-3' & \\
\hline \multirow{2}{*}{ CXCR2 } & 5'-AGT GCC TGC CTC AAT GTC TCC A-3' & \multirow{2}{*}{249} \\
\hline & 5'-CCA GGA GCA AGG ACA GAC CCC-3' & \\
\hline \multirow{2}{*}{ CCR5 } & 5'-CAA GAC ATT CCT GAT CGT GCA A-3' & \multirow{2}{*}{129} \\
\hline & 5'-TCC TAC CAA GCT GCA TAG AA-3' & \\
\hline \multirow{2}{*}{ CCR1 } & 5'-TGC AGG TGA CTG AGG TGA TTG-3' & \multirow{2}{*}{108} \\
\hline & 5'-TGA AAC AGC TGC CGA AGG TAC-3' & \\
\hline
\end{tabular}

HPRT: housekeeping gene hypoxanthine phosphoribosyltransferase; bp: base pairs of amplicon size.

\section{Results}

Real-time PCR analysis of the mRNA expression levels of the chemokines CCL5, CXCL10, and CCL2/ MCP-1 and the chemokine receptors CCR5, CXCR2, and CCR1 was performed using samples from the periradicular tissues of axenic mice. No significant differences in CCR5 and CCL5 expression were found at either 7 or 14 days post-inoculation with a microbial association consisting of $F$. nucleatum and $E$. faecalis (Figure 1). However, the microbial association induced significantly increased gene expression at 7 to 14 days of the chemokines CXCL10, CCL2/MCP-1, CXCR2, and CCR1 (Figure 2). As expected, the absence of the microbial stimulus (i.e., only the RCS instrumentation was performed in the control group) was unable to induce a change in gene expression of the evaluated chemokines at either 7 or 14 days.

\section{Discussion}

From the moment at which the organism is challenged by the microbiota, the inflammatory process begins in an attempt to limit or even eliminate the microbial invasion. ${ }^{2,3,23,24}$ Several studies have 

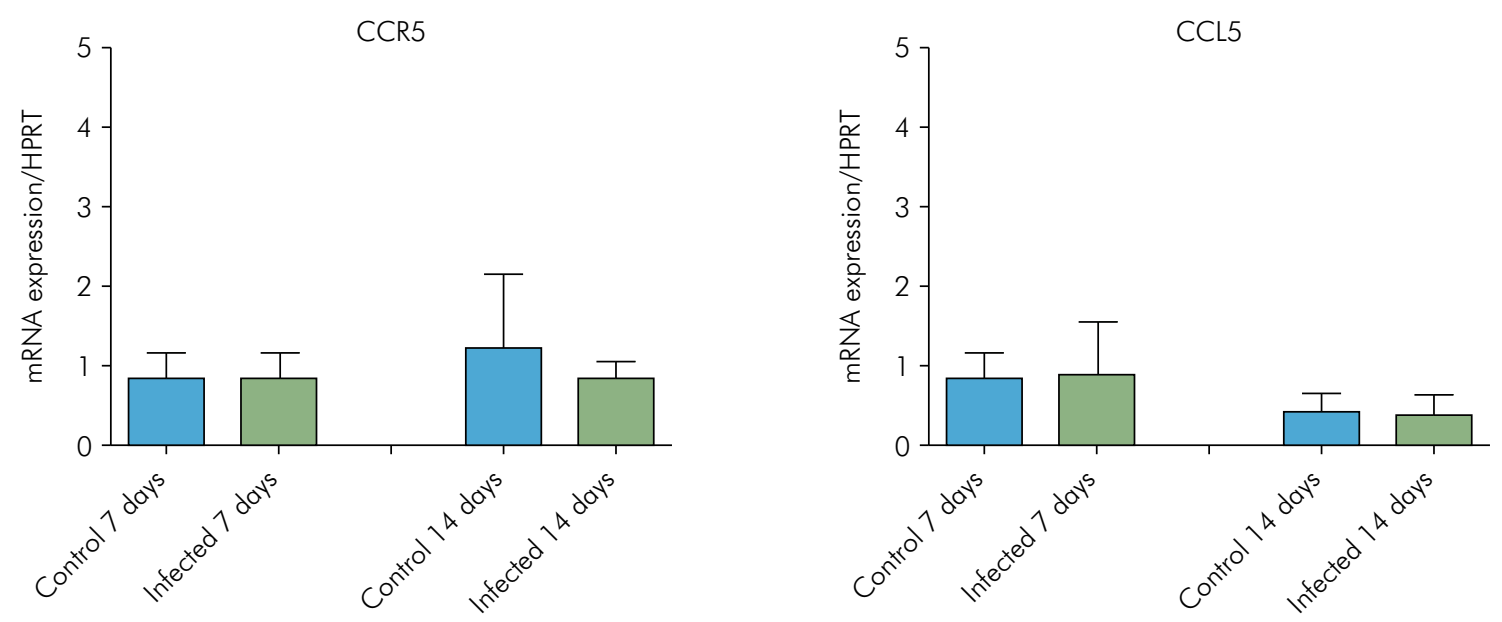

Figure 1. mRNA expression of the chemokines CCR5 and CCL5 analysed by real-time PCR in response to experimental infection in GF mice by microbial bi-association of $E$. faecalis, and F. nucleatum. The relative mRNA expression levels were quantified compared with those of the internal control (HPRT). The data were expressed as the mean \pm standard error of two independent experiments with six mice per group. The bars represent the mean values of the samples recovered from the axenic mice, and the error bars represent the standard errors of the means.

shown that endodontic infections have a polymicrobial aetiology. ${ }^{25,26,27,28}$ With an aim of analysing the effects of the microbiota on adjacent periradicular tissues, researchers have promoted exposure of the pulp to non-specific microbes in the oral cavity. ${ }^{29,30,31}$ Conversely, the use of GF animals has enabled the induction of a known endodontic infection, which allows evaluation of its effects in a specific manner. ${ }^{2,67,7,20}$ Moreover, gnotobiotic animals are good models for the study of periapical pathologies, because synergistic effects or antagonistic influences of the resident microbiota or its derivatives can be detected. These animal models are also instrumental in determining the true effect and identity of the aetiological agent of an infectious disease. $6,7,8,9,32$

The ability of bacteria to implant into specific sites in an organism is dependent on their concentrations, numbers, virulence, and host resistance. ${ }^{33}$ In this study, two microorganisms prevalent in endodontic infections (Enterococcus faecalis (ATCC 19433), Gram-positive, and Fusobacterium nucleatum (ATCC 10953), Gram-negative, were selected to conduct an experimental infection in GF mice. Previously evaluated concentrations that were capable of inducing colonization by these microorganisms were used. ${ }^{6,8,9,20}$ Among the factors that affect bacterial growth and RCS colonization, the potential for oxidation-reduction, microbial interactions, and available substrates is critical. ${ }^{33}$ In this study, E. faecalis (facultative anaerobe) reduced the oxidationreduction potential, thereby improving F. nucleatum growth..$^{20}$ Additionally, the strains were demonstrated to show no antagonism against each other. ${ }^{34}$

Periradicular tissues respond to endodontic infection by expressing a series of mediators that seek to limit infection within the RCS, which leads to the destruction of adjacent tissues via the release of soluble mediators derived from the host. ${ }^{35}$ Researchers using a murine experimental model to analyse the development of periapical lesions demonstrated that an active phase occurred at 7 days, followed by a chronic phase from 14 days. ${ }^{67,729,36,37}$ In agreement with these findings, the results of this study demonstrated greater CCL-2 gene expression during the initial phase of periapical lesion development. Similar results have been previously reported. ${ }^{31}$ Conversely, in humans, the CCL2 and CCL-5 levels did not change after mechanical-chemical preparation and consequent reduction of the root canal microbial load. ${ }^{38}$ CCL2/ MCP- 1 and CCL 5 are a specialized group of cytokines that coordinate the movement of leukocytes into tissues. ${ }^{11}$ These cytokines are involved in multiple biological processes, including organ development and homeostasis, angiogenesis, and activation and regulation of immunity. ${ }^{39}$ 

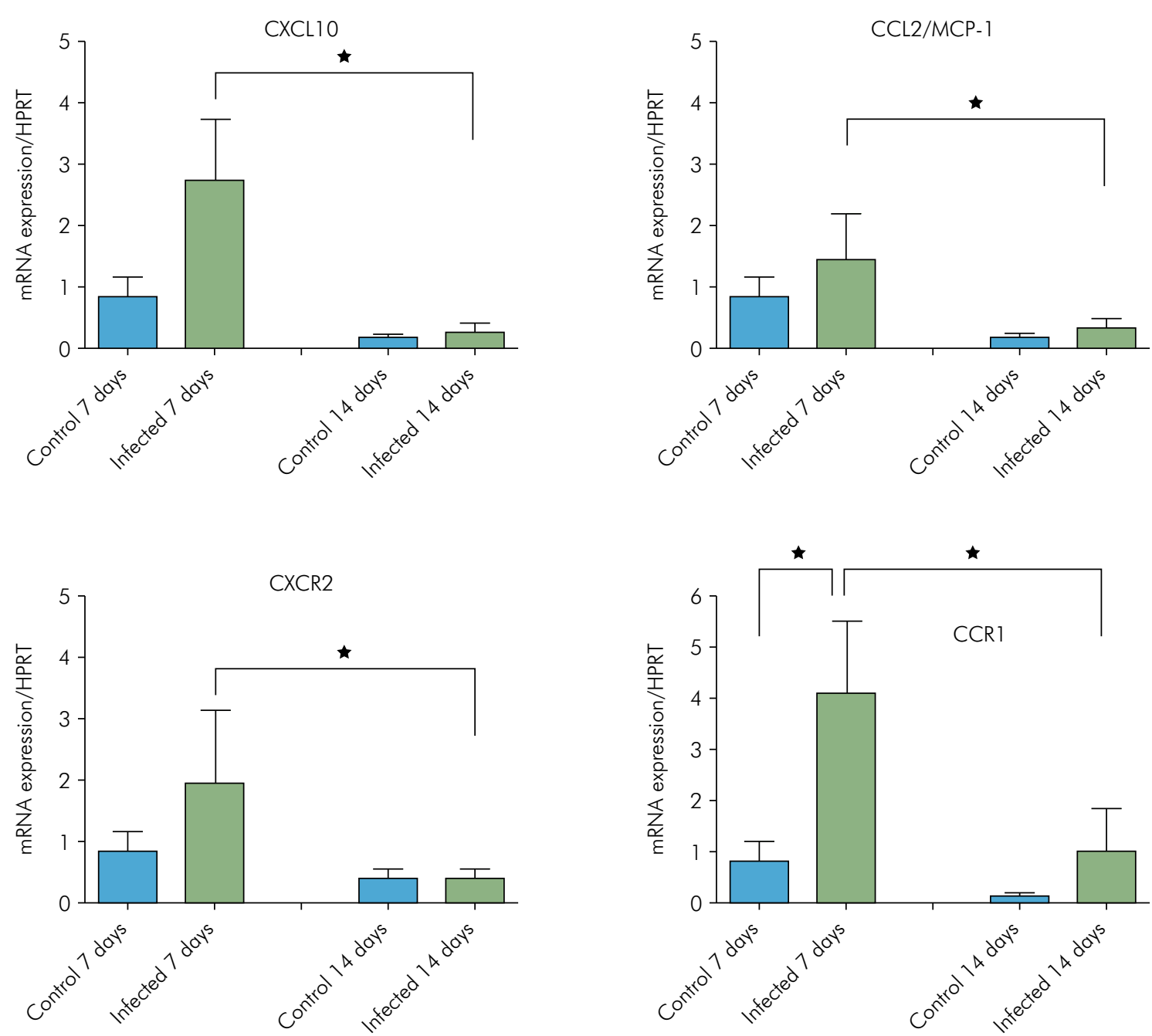

Figure 2. mRNA expression of the chemokines CXCL10, CCL2/MCP-1, CXCR2 and CCR1 analysed by real-time PCR in response to experimental infection in GF mice by microbial bi-association of $E$. faecalis, and F. nucleatum. The relative mRNA expression levels were quantified compared with those of the internal control (HPRT). The data were expressed as the mean \pm standard error of two independent experiments with six mice per group. The bars represent the mean values of the samples recovered from the axenic mice, and the error bars represent the standard errors of the means. $\mathrm{P}<0.05$ as determined by Student's t-test.

CXCL10 is a CXC family chemokine that is related to polymorphonuclear cell chemotaxis and angiogenesis. ${ }^{10}$ In this study, higher CXCL10 expression was observed on day 7 of the 14-day study, demonstrating its involvement in the active phase of periradicular lesion development, as observed with CCL-2. Consistent with this finding, studies have also demonstrated elevated CXCL10 expression after stimulation of inflammatory cells in vitro. ${ }^{19,40}$

CCR5, CCR1, and CXCR2 are chemokine receptors. A receptor can bind to more than one chemokine due to redundancy of its activity. ${ }^{13}$ Consistent with the higher chemokine expression observed on day 7 of the 14-day study, high CCR1 and CXCR2 levels were observed at the first evaluation period. Similar results for CXCR2 were also demonstrated in murine experimental non-specific endodontic infections. ${ }^{18}$ In the present study, baseline CCR5 expression levels were observed in both the control and experimental groups during the two evaluated periods. Furthermore, knockout mice for the CCR5 receptor developed greater periapical lesions than wild-type mice. ${ }^{17}$ In humans, results similar to those presented here were found, with no change in the 
CCR5 expression levels after mechanical-chemical preparation of the RCS and consequent reduction of the microbial load. ${ }^{38}$ Taken together, the results of this study demonstrate that the events in the apical area after E. faecalis and Fusobacterium nucleatum colonize the RCS interfere with the expression of chemokines and their receptors.

\section{Conclusion}

The gnotoxenic animal model proved to be effective for evaluation of the immune response against a known infection. Additionally, this study demonstrated that

\section{References}

1. Jontell M, Okiji T, Dahlgren U, Bergenholtz G. Immune defense mechanisms of the dental pulp. Crit Rev Oral Biol Med. 1998;9(2):179-200. https://doi.org/10.1177/10454411980090020301

2. Kakehashi S, Stanley HR, Fitzgerald RJ. The effects of surgical exposures of dental pulps in germ-free and conventional laboratory rats. Oral Surg Oral Med Oral Pathol. 1965 Sep;20(3):340-9. https://doi.org/10.1016/0030-4220(65)90166-0

3. Sundqvist G. Bacteriological studies of necrotic pulps [dissertation]. Umeá, Sweden: Umea University Odontological;1976.

4. Bambirra Junior W, Maciel KF, Thebit MM, Brito LC, Vieira LQ, Ribeiro Sobrinho AP. Assessment of apical expression of alpha-2 integrin, heat shock protein, and proinflammatory and immunoregulatory cytokines in response to endodontic infection. J Endod. 2015 Jul;41(7):1085-90. https://doi.org/10.1016/j.joen.2015.03.002

5. Sette-Dias AC, Maciel KF, Abdo EN, Brito LC, Carvalho MA, Vieira LQ et al. Cytokine Expression in Patients Hospitalized for Severe Odontogenic Infection in Brazil. J Endod. 2016 May;42(5):706-10. https://doi.org/10.1016/i.joen.2016.01.018

6. Ribeiro Sobrinho AP, Maltos SMM, Farias LM, Carvalho MA, Nicoli JR, Uzeda M et al. Cytokine production in response to endodontic infection in germ-free mice. Oral Microbiol Immunol. 2002 Dec;17(6):344-53. https://doi.org/10.1034/j.1399-302X.2002.170603.x

7. Ribeiro-Sobrinho AP, Rabelo FL, Figueiredo CB, Alvarez-Leite Jl, Nicoli JR, Uzeda M, et al. Bacteria recovered from dental pulp induce apoptosis of lymph node cells. J Med Microbiol. 2005 Apr;54(Pt 4):413-6. https://doi.org/10.1099/jmm.0.45728-0

8. Moreira Júnior G, Ribeiro Sobrinho AP, Bambirra BH, Bambirra FH, Carvalho MA, Farias LM et al. Synergistic growth effect among bacteria recovered from root the gene expression of chemokines and their receptors against the experimental infection preferentially prevailed during the initial phase of induction of the periradicular alteration, confirming that the migration of cells to the surrounding tissues occurred in the presence of noxious agents within the RCS to promote much needed immunological surveillance.

\section{Acknowledgements}

This work was supported by Fapemig, Capes, and CNPq. The authors wish to thank the postgraduate programme at the School of Dentistry of UFMG. LQV and APRS are CNPq fellows.

canal infections. Braz J Microbiol. 2011 Jul;42(3):973-9. https://doi.org/10.1590/S1517-83822011000300017

9. Maciel KF, Brito LCN, Tavares WL, Moreira G, Nicoli JR, Vieira $L Q$ et al. Cytokine expression in response to root canal infection in gnotobiotic mice. Int Endod J. 2012 Apr;45(4):354-62. https://doi.org/10.1111/j.1365-2591.2011.01983.x

10. Charo IF, Ransohoff RM. The many roles of chemokines and chemokine receptors in inflammation. N Engl J Med. 2006 Feb;354(6):610-21. https://doi.org/10.1056/NEJMra052723

11. Hahn CL, Liewehr FR. Update on the adaptive immune responses of the dental pulp. J Endod. 2007 Jul;33(7):773-81. https://doi.org/10.1016/i.joen.2007.01.002

12. Cintra LT, Samuel RO, Azuma MM, Queiróz AO, Ervolino E, Sumida DH et al. Multiple apical periodontitis influences sérum levels of cytokines and nitric oxide. J Endod. 2016 May;42(5):747-51. https://doi.org/10.1016/i.joen.2016.01.022

13. Bachelerie F, Ben-Baruch A, Burkhardt AM, Combadiere C, Farber JM, Graham GJ et al. International Union of Basic and Clinical Pharmacology. [corrected]. LXXXIX. Update on the extended family of chemokine receptors and introducing a new nomenclature for atypical chemokine receptors. Pharmacol Rev. 2013 Nov;66(1):1-79. https://doi.org/10.1124/pr.113.007724

14. Silva TA, Garlet GP, Lara VS, Martins Junior W, Silva JS, Cunha FQ. Differential expression of chemokines and chemokine receptors in inflammatory periapical diseases. Oral Microbiol Immunol. 2005 Oct;20(5):310-6. https://doi.org/10.1111/i.1399-302X.2005.00232.x

15. Silva TA, Garlet GP, Fukada SY, Silva JS, Cunha FQ. Chemokines in oral inflammatory diseases: apical periodontitis and periodontal disease. J Dent Res. 2007 Apr;86(4):306-19. https://doi.org/10.1177/154405910708600403 
16. Kawashima N, Suzuki N, Yang G, Ohi C, Okuhara $\mathrm{S}$, Nakano-Kawanishi $\mathrm{H}$ et al. Kinetics of RANKL, RANK and OPG expressions in experimentally induced rat periapical lesions. Oral Surg Oral Med Oral Pathol Oral Radiol Endod. 2007 May;103(5):707-11. https://doi.org/10.1016/i.tripleo.2006.11.036

17. De Rossi A, Rocha LB, Rossi MA. Interferon-gamma, interleukin-10, Intercellular adhesion molecule-1, and chemokine receptor 5, but not interleukin-4, attenuate the development of periapical lesions. J Endod. 2008 Jan;34(1):31-8. https://doi.org/10.1016/j.joen.2007.09.021

18. Yamanaka Y, Kaneko T, Yoshiba K, Kaneko R, Yoshiba $N$, Shigetani $Y$ et al. Expression of angiogenic factors in rat periapical lesions. J Endod. 2012 Mar;38(3):313-7. https://doi.org/10.1016/i.joen.2011.11.009

19. Takegawa D, Nakanishi T, Hirao K, Yumoto H, Takahashi K, Matsuo T. Modulatory roles of interferon- $\gamma$ through indoleamine 2, 3-dioxygenase induction in innate immune response of dental pulp cells. J Endod. 2014 Sep;40(9):13827. https://doi.org/10.1016/i.joen.2014.03.018

20. Maltos KL, Menezes GB, Caliari MV, Rocha OA, Santos JM, Alves DL et al. Vascular and cellular responses to pro-inflammatory stimuli in rat dental pulp. Arch Oral Biol. 2004 Jun;49(6):443-50. https://doi.org/10.1016/i.archoralbio.2004.01.004

21. Lara VP, Cardoso FP, Brito LC, Vieira LQ, Ribeiro Sobrinho AP, Rezende TM. Experimental furcal perforation treated with MTA: analysis of the cytokine expression. Braz Dent J. 2015 Jul-Aug;26(4):337-41. https://doi.org/10.1590/0103-6440201300006

22. Silva MJB, Vieira $L Q$, Ribeiro Sobrinho AP. The effects of mineral trioxide aggregates on cytokine production by mouse pulp tissue. Oral Surg Oral Med Oral Pathol Oral Radiol Endod. 2008 May;105(5):e70-6. https://doi.org/10.1016/j.tripleo.2008.01.025

23. Moller AJ. Microbiological examination of root canals and periapical tissues of human teeth. Odontol Tidskr. $1966 \mathrm{Dec}$ 20;74(5 Suppl):1-380.

24. Márton IJ, Kiss C. Overlapping protective and destructive regulatory pathways in apical periodontitis. J Endod. 2014 Feb;40(2):155-63. https://doi.org/10.1016/i.joen.2013.10.036

25. Siqueira Juniro JF, Rôças IN, Rosado AS. Investigation of bacterial communities associated with asymptomatic and symptomatic endodontic infections by denaturing gradient gel electrophoresis fingerprinting approach. Oral Microbiol Immunol. 2004 Dec;19(6):363-70. https://doi.org/10.1111/j.1399-302x.2004.00170.x

26. Siqueira Junior JF, Rôças IN. Uncultivated phylotypes and newly named species associated with primary and persistent endodontic infections. J Clin Microbiol. 2005 Jul;43(7):3314-9. https://doi.org/10.1128/JCM.43.7.3314-3319.2005

27. Jacinto RC, Gomes BP, Shah HN, Ferraz CC, Zaia AA, SouzaFilho FJ. Quantification of endotoxins in necrotic root canals from symptomatic and asymptomatic teeth. J Med Microbiol. 2005 Aug;54(Pt 8):777-83. https://doi.org/10.1099/jmm.0.45976-0
28. Tavares WL, Brito LCN, Teles RP, Massara ML, Ribeiro Sobrinho AP, Haffajee AD et al. Microbiota of deciduous endodontic infections analysed by MDA and Checkerboard DNA-DNA hybridization. Int Endod J. 2011 Mar;44(3):225-35. https://doi.org/10.1111/j.1365-2591.2010.01805.x

29. Kawashima N, Stashenko P. Expression of boneresorptive and regulatory cytokines in murine periapical inflammation. Arch Oral Biol. 1999 Jan;44(1):55-66. https://doi.org/10.1016/S0003-9969(98)00094-6

30. AlShwaimi E, Purcell P, Kawai T, Sasaki H, Oukka M, Campos-Neto A et al. Regulatory $T$ cells in mouse periapical lesions. J Endod. 2009 Sep;35(9):1229-33. https://doi.org/10.1016/i.joen.2009.06.006

31. Silva MJ, Sousa LM, Lara VP, Cardoso FP, Vieira Júnior GM, Totola $\mathrm{AH}$ et al. The role of iNOS and PHOX in periapical bone resorption. J Dent Res. 2011 Apr;90(4):495-500. https://doi.org/10.1177/0022034510391792

32. de Melo Maltos SM, Ribeiro Sobrinho AP, Silva FV, Nicoli JR, Carvalho MAR, Vieira LQ et al. Bacterial concentrations determine the ability to implant in the root canal system and translocate to lymph nodes in germ-free mice. J Endod. 2003 Jan;29(1):24-7. https://doi.org/10.1097/00004770-200301000-00007

33. Sundqvist $G$. Associations between microbial species in dental root canal infections. Oral Microbiol Immunol. 1992 Oct;7(5):257-62. https://doi.org/10.1111/i.1399-302X.1992. tb00584.x PMID:1494447

34. Ribeiro Sobrinho AP, Barros MH, Nicoli JR, Carvalho MA, Farias LM, Bambirra EA et al. Experimental root canal infections in conventional and germ-free mice. J Endod. 1998 Jun;24(6):4058. https://doi.org/10.1016/S0099-2399(98)80021-6

35. Stashenko P, Teles R, D'Souza R. Periapical inflammatory responses and their modulation. Crit Rev Oral Biol Med. 1998;9(4):498-521. https://doi.org/10.1177/10454411980090040701

36. Stashenko P, Yu SM, Wang CY. Kinetics of immune cell and bone resorptive responses to endodontic infections. J Endod. 1992 Sep;18(9):422-6. https://doi.org/10.1016/S0099-2399(06)80841-1

37. Stashenko P, Wang CY, Tani-Ishii N, Yu SM. Pathogenesis of induced rat periapical lesions. Oral Surg Oral Med Oral Pathol. 1994 Oct;78(4):494-502. https://doi.org/10.1016/0030-4220(94)90044-2

38. Brito LC, Teles FR, Teles RP, Totola AH, Vieira LQ, Ribeiro Sobrinho AP. T-lymphocyte and cytokine expression in human inflammatory periapical lesions. J Endod. 2012 Apr;38(4):481-5. https://doi.org/10.1016/i.joen.2011.12.010

39. Bryant VL, Slade CA. Chemokines, their receptors and human disease: the good, the bad and the itchy. Immunol Cell Biol. 2015 Apr;93(4):364-71. https://doi.org/10.1038/icb.2015.23

40. Durand SH, Flacher V, Roméas A, Carrouel F, Colomb E, Vincent $C$ et al. Lipoteichoic acid increases TLR and functional chemokine expression while reducing dentin formation in in vitro differentiated human odontoblasts. J Immunol. 2006 Mar;176(5):2880-7. https://doi.org/10.4049/jimmunol.176.5.2880 